\title{
Bovine Serum Albumin Antibodies as a Disease Marker for Hepatitis E Virus Infection
}

\author{
Medhat Haroun \\ Department of Bioscience \& Technology, Institute of Graduate Studies \& Research, Alexandria University, \\ 163 Horreya Avenue, PO Box 832, Chatby 21526, Alexandria, Egypt
}

Received 4 March 2005; revised 1 June 2005; accepted 7 June 2005

\begin{abstract}
This report evaluates the significance of antibody/bovine serum albumin (BSA) interactions as a risk factor for the diagnosis of acute hepatitis E. Serum samples from 40 patients with acute hepatitis E and from 40 age/sex matched healthy adult subjects were tested for IgA, IgG, and IgM by ELISA and by turbidimetric assay. BSA was used as a target to characterize changes in levels of interacting immunoglobulins. Initial results obtained before removal of antibodies that interacted with BSA suggested that HEV patients had increased levels of IgM in their sera. It was found that normal individuals had mean IgA, IgG, and IgM levels of $2.55 \mathrm{mg} / \mathrm{mL}, 9.80 \mathrm{mg} / \mathrm{mL}$, and $1.73 \mathrm{mg} / \mathrm{mL}$, respectively while HEV patients had mean levels of $2.66 \mathrm{mg} / \mathrm{mL}, 10.04 \mathrm{mg} / \mathrm{mL}$, and $2.01 \mathrm{mg} / \mathrm{mL}(P<.26, P<.32$, and $P<.0004)$. However, the mean level of IgM in HEV-infected sera after purification from antibodies that interacted with BSA was determined to be $1.72 \mathrm{mg} / \mathrm{mL}$ indicating that there was no significant difference in IgM level in HEV patients compared to normal individuals $(P<.6)$. The presence of antibodies that interact with BSA might serve as a diagnostic tool for detection of high-risk patients.
\end{abstract}

\section{INTRODUCTION}

Hepatitis $\mathrm{E}$ is the first or second most important cause of acute clinical hepatitis in many developing countries of Asia, the Middle East, and North Africa. Hepatitis E can occur sporadically or in epidemics and the peak clinical attack rate usually occurs in young adults $[1,2,3,4]$. Hepatitis E is caused by the hepatitis E virus (HEV) which is a single-stranded sense strand RNA virus similar to Caliciviruses that is enterically transmitted. Although sporadic HEV infections have occurred in industrialized nations, there is an unexpectedly high prevalence of antibodies to HEV (anti-HEV) (as high as 21.3\%) among blood donors in the United States, where hepatitis $\mathrm{E}$ is not endemic [5]. Enzyme immunoassays based on recombinant proteins of HEV have been used for most seroprevalence studies. A wide range of sensitivity and specificity has been reported for these assays $[6,7,8,9]$. This information implies that these assays might be unreliable

Correspondence and reprint requests to Medhat Haroun, Department of Bioscience \& Technology, Institute of Graduate Studies \& Research, Alexandria University, 163 Horreya Avenue, PO Box 832, Chatby 21526, Alexandria, Egypt; E-mail: mharounag@yahoo.com

This is an open access article distributed under the Creative Commons Attribution License which permits unrestricted use, distribution, and reproduction in any medium, provided the original work is properly cited. for the diagnosis of HEV infection in areas where hepatitis $\mathrm{E}$ is not endemic. However, diagnosis of acute hepatitis $\mathrm{E}$ by detection of hepatitis $\mathrm{E}$ virus (HEV)-specific immunoglobulin $\mathrm{M}(\operatorname{IgM})$ is an established procedure $[10,11,12,13]$. The measurement of antibodies to hepatitis $\mathrm{E}$ virus has been essential for understanding the epidemiology of hepatitis E. In this study, we investigated whether serum level quantification of HEV-specific IgA, IgG, and IgM together furnished novel insight into infection and immunity.

Antibodies, which bind other proteins, may add another facet to the abnormal immune response of HEV. Variations in immunoreactivities and a limited window for the persistence of antibodies to various epitopes may account for such diagnostic failures. Bovine serum albumin is one of the most widely studied proteins; its structure is well known and its antigenic characteristics have been described in several papers $[14,15]$. The present study was therefore designed to delineate heterophile antibody interference in our ELISA detection and to propose strategies for resolving the problem. We attempted to determine whether there are specific aspects of using BSA to determine whether antibodies that interact with BSA provide any diagnostic value as a risk factor for acute hepatitis $\mathrm{E}$ using ELISA. In addition, the sensitivities of immunoassays for antibodies to HEV may be increased by including antigens such as BSA. Despite this complexity, data in this study demonstrates more reliable results for IgM quantification after they have been purified from antibodies that interact with BSA than for IgM quantification without such purification. 


\section{SUBJECTS AND METHODS}

Anti-human $\operatorname{IgA}(\mathrm{G}, \mathrm{M})$ antiserum (raised in rabbit), human IgA (G, M), rabbit anti-human IgA (G, M) conjugated to horseradish peroxidase (HRP), and tetramethylbenzidine were purchased from Sigma (Sigma-Aldrich Company Ltd, UK) and all other chemicals were supplied from BDH (VWR International Ltd, UK).

\section{Subjects}

Informed patient consent was obtained in every case and the use of blood for scientific studies was approved by the local Ethical Committee. Sera were collected from 40 patients with a clinical diagnosis of acute hepatitis. Serological diagnosis was based on the detection of antihepatitis A virus (anti-HAV) IgM, hepatitis B virus (HBV) markers (anti-HBV core IgM, HBV surface antigen, HBV antigen), anti-hepatitis $\mathrm{C}$ virus (anti-HCV) IgG, and anti-HEV IgG. Anti-HEV IgG was detected by using an assay from Genelabs Technologies, Inc (USA). Forty patients who were diagnosed with hepatitis E fulfilled these conditions and were admitted to the study. Forty participants unaffected by HEV were selected as a control group. Affected and unaffected groups were matched for age and sex (median age was 31 years ranging from 21 to 42 years). Medical history, physical examination, and routine laboratory investigations were completely normal in all unaffected subjects. They did not use any medication prior to this study. All sera were collected within four months and stored in small aliquots at $-80^{\circ} \mathrm{C}$ until tested under code.

\section{Electrophoresis of immuno-precipitates on polyacrylamide gel}

Human serum samples were immuno-precipitated with anti-human IgM developed in rabbit in the presence or absence of BSA. Serum samples $(25 \mu \mathrm{L})$ were diluted with either 1x PBS $(475 \mu \mathrm{L})$ or BSA $(56 \mu \mathrm{L}$, at a concentration of $50 \mathrm{mg} / \mathrm{mL}$ solution in $1 \mathrm{x}$ PBS) diluted with $1 \mathrm{x}$ PBS $(419 \mu \mathrm{L})$ in addition, $75 \mu \mathrm{L}$ of anti-IgM antiserum with 1x PBS $(425 \mu \mathrm{L})$. After dilution, the antiserum and serum were mixed to give a final volume of $1 \mathrm{~mL}$ and incubated for $1 \mathrm{~h}$ at room temperature. The precipitate was removed by centrifugation at $13000 \mathrm{rpm}$ for $5 \mathrm{~min}$ in micro centrifuge and then washed with $200 \mu \mathrm{L} \mathrm{1x}$ PBS. The antigen-antibody precipitate was dissolved in $50 \mu \mathrm{L}$ of $2 \mathrm{x}$ Laemmli sample buffer $(0.125 \mathrm{M}$ Tris- $\mathrm{HCl}$ $\mathrm{pH}(6.8), 0.1 \%(\mathrm{w} / \mathrm{v})$ SDS, $20 \%(\mathrm{w} / \mathrm{v})$ glycerol, $0.005 \%$ $(\mathrm{w} / \mathrm{v})$ bromophenol blue) and then incubated at $95^{\circ} \mathrm{C}$ for 3 min [16]. A fraction of this mixture $(25 \mu \mathrm{L})$ was electrophoresed overnight on a $10 \%$ polyacrylamide gel at a constant voltage of $45 \mathrm{~V}$ at room temperature. Following electrophoresis, proteins were visualized by staining with Coomassie blue staining [17].

\section{Human immunoglobulin measurement by ELISA}

Coating antibody (anti-human $\operatorname{IgA}$ (IgG, IgM) antiserum) was diluted 1 in 1000 in $1 \mathrm{x}$ coating buffer (0.02 M Tris- $\mathrm{HCl}, 1.5 \mathrm{M} \mathrm{NaCl} \mathrm{pH} \mathrm{9.0)} \mathrm{and} 100 \mu \mathrm{L}$ was added to each of the wells of a microtiter plate $[18,19]$. After overnight incubation at $4{ }^{\circ} \mathrm{C}$ the plate was washed 4 times with PBST20 $(0.1 \%(\mathrm{w} / \mathrm{v})$ [Tween 20 in $1 \mathrm{x}$ PBS (phosphate-buffered saline; $0.25 \mathrm{M} \mathrm{NaCl}, 0.0268 \mathrm{M} \mathrm{KCl}$, $0.081 \mathrm{M} \mathrm{Na}_{2} \mathrm{HPO}_{4}$, and $\left.\left.0.0146 \mathrm{M} \mathrm{KH}_{2} \mathrm{PO}_{4}\right)\right]$ ). Sites unoccupied by antibody were blocked by addition of $5 \%(\mathrm{w} / \mathrm{v})$ Marvel (dried skimmed milk) in PBS for $1 \mathrm{~h}$ at room temperature followed by washing 6 times with PBST20. The human serum samples were initially diluted 1 in 2000 in 1x PBS, and 2 fold serial dilutions subsequently performed on the plate. Diluted samples were allowed to bind to the first antibody and the plate was then washed 6 times in PBST20.

Rabbit anti-human IgA (IgG, IgM) conjugated to HRP (second antibody) was diluted 1 in 1000 in 1x PBS, $100 \mu \mathrm{L}$ was added to each well of the microtiter plate, incubated at room temperature for $1 \mathrm{~h}$ and then washed 6 times in PBST20. The amount of bound second antibody was determined by adding $200 \mu \mathrm{L}$ of the substrate solution (tetramethylbenzidine $6 \mathrm{mg} / \mathrm{mL}$ in $0.1 \mathrm{M}$ sodium acetate buffer $\mathrm{pH}$ 6.0) to each well. After incubation in the dark at room temperature for $20 \mathrm{~min}$, the reaction was stopped by adding $50 \mu \mathrm{L}$ of $10 \%(\mathrm{w} / \mathrm{v}) \mathrm{H}_{2} \mathrm{SO}_{4}$ to each well. The optical density of each sample was read with an ELISA plate reader with a $450 \mathrm{~nm}$ filter. A standard curve was constructed by plotting absorbance against concentration for the standard solutions and the concentration of immunoglobulin $(\mathrm{mg} / \mathrm{mL})$ in the samples was determined.

\section{Human immunoglobulin M measurement by turbidimetric assay}

Human serum samples were titrated previously against antisera to obtain the optimum optical densities (optimal precipitation) [20]. Briefly, $8 \mu \mathrm{L}$ of human serum samples was diluted with $492 \mu \mathrm{L}$ of 1x PBS and, in addition, $25 \mu \mathrm{L}$ of anti-IgM antiserum (dev eloped in rabbit) with $475 \mu \mathrm{L}$ of $1 \mathrm{x}$ PBS. After dilution, the antiserum and serum were mixed and incubated for $1 \mathrm{~h}$ at room temperature. At the same time, the standard human IgM was titrated by adding equal volumes of antiserum, mixed well and incubated for $1 \mathrm{~h}$ at room temperature. The degree of precipitation was quantified by measuring the optical density at $600 \mathrm{~nm}$. The concentration of IgM $(\mathrm{mg} / \mathrm{mL})$ was calculated from the standard dilution series.

\section{Purification of HEV-infected sera from the effect of antibodies that interact with BSA}

Bovine serum albumin, $56 \mu \mathrm{L}$, at a concentration of $50 \mathrm{mg} / \mathrm{mL}$ solution in $1 \mathrm{x}$ PBS, $\mathrm{pH}$ 7.2, was mixed with $200 \mu \mathrm{L}$ of human serum samples (diluted 1 in 10) to minimize further cross-reactivity to BSA. The absorption was carried out for $1 \mathrm{~h}$ at $37^{\circ} \mathrm{C}$, followed overnight at $4^{\circ} \mathrm{C}$. The human sera were clarified by centrifugation at $10000 \mathrm{xg}$ for $20 \mathrm{~min}$ at $4^{\circ} \mathrm{C}$ before testing [21, 22]. The absorption of human sera with BSA completely removed the positive reaction of BSA antibodies, and then the concentration of immunoglobulin present in each of these samples was determined by ELISA as described above. 


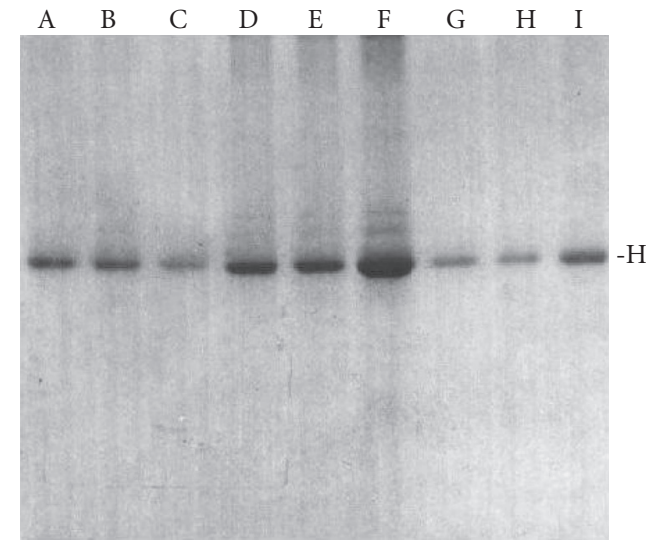

FIGURE 1. Immuno-precipitation and polyacrylamide gel electrophoresis of human serum samples with anti-human IgM. Three HEV-infected serum samples were immuno-precipitated with anti-IgM antiserum developed in rabbit in the absence (lanes A, B, and C resp) or presence of BSA (lanes F, E, and D resp). Lane $\mathrm{H}$ contained one normal serum sample in the absence of BSA and Lane G contained the same normal serum sample in the presence of BSA. Lane I represents standard human IgM. $\mathrm{H}$ indicates positions of immunoglobulin heavy chains. The precipitates were washed, dissolved in Laemmli sample buffer, and analyzed by polyacrylamide gel electrophoresis.

\section{Statistical analysis}

After tabulating the data, the arithmetic mean for each group was calculated using SPSS for Windows. The variation in each group was represented by the standard deviation (SD). The means of the groups were compared to see if the differences were significant. Student $t$ test was used to assess the significance of the difference between groups.

\section{RESULTS}

The possibility that immunoglobulins from HEVinfected sera bind and coprecipitate with BSA more than do immunoglobulins from unaffected individuals was investigated using polyacrylamide gel electrophoresis. Three sera from HEV-infected patients and one serum sample from an unaffected participant were immuoprecipitated in the presence or absence of BSA and the immunoprecipitates were electrophoresed on a polyacrylamide gel (Figure 1). Visual examination of Figure 1 shows that the pretreatment of HEV-infected sera with BSA reduces the intensity of a band that coprecipitates with the antigen-antibody complex and comigrates with the IgM heavy chain.

It is not possible to differentiate between $\operatorname{IgM}$ and other immunoglobulin heavy chains using polyacrylamide gel electrophoresis therefore ELISA measurements were carried out with or without pretreatment with BSA to determine if this increased interaction included IgM. Sera from individuals unaffected or affected with HEV where allocated to two groups (A and B). Each serum sample in group A (from unaffected individuals) was

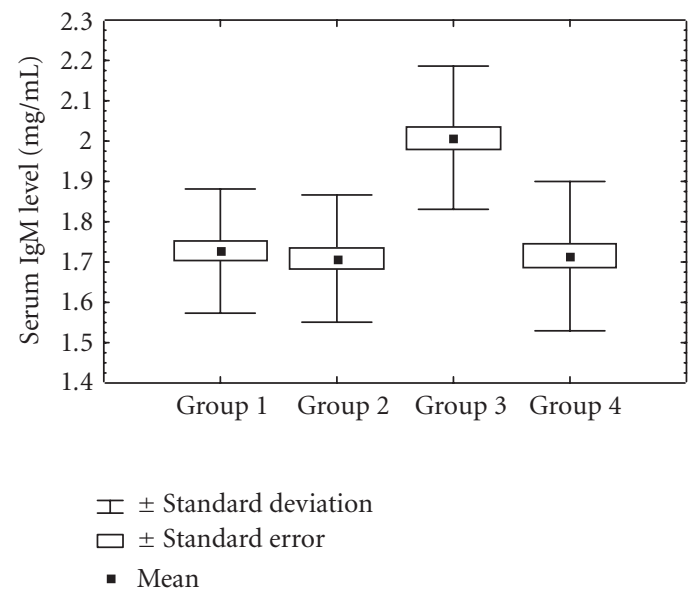

Figure 2. Serum IgM levels in groups of HEV-infected sera and unaffected control measured by ELISA. Comparison of average serum IgM (mean $\pm \mathrm{SD})$.

Table 1. Statistical analysis of IgA and IgG measured by ELISA. (Values are mean \pm SD.)

\begin{tabular}{cccc}
\hline $\begin{array}{c}\text { Study } \\
\text { group }\end{array}$ & Case & $\begin{array}{c}\text { Serum IgA level } \\
(\mathrm{mg} / \mathrm{mL})\end{array}$ & $\begin{array}{c}\text { Serum IgG level } \\
(\mathrm{mg} / \mathrm{mL})\end{array}$ \\
\hline $1(\mathrm{n}=40)$ & Normal & $2.55 \pm 0.51$ & $9.80 \pm 0.98$ \\
$3(\mathrm{n}=40)$ & HEV patients & $2.66 \pm 0.39^{\#}$ & $10.04 \pm 1.09^{*}$ \\
\hline
\end{tabular}

${ }^{\#} P<.26 ;{ }^{*} P<.32$ compared with normal individuals.

divided into two and assigned to groups 1 and 2 and each sample in group B (from HEV-affected individuals) was assigned to groups 3 and 4 . Groups 1 and 3 were untreated while groups 2 and 4 were treated as outlined in "subjects and methods" ("purification of HEV-infected sera from the effect of antibodies that interact with BSA"). Unaffected and HEV-affected sera were pretreated with BSA to investigate whether this would affect the IgM level as measured by ELISA. Results (Figure 2) demonstrated that pretreatment of sera with BSA prior to ELISA affected IgM levels but that this dramatically reduced the level of IgM in the sera from HEV patients (group 4) while sera from unaffected individuals (group 2) were barely affected by this treatment. The quantitative analysis of serum IgM level (mean \pm SD) found that group 1 had a mean level of IgM of $1.73 \pm 0.154 \mathrm{mg} / \mathrm{mL}$ which was lower than group $3(2.01 \pm 0.178 \mathrm{mg} / \mathrm{mL})$. This represented a significant increase in IgM level in the sera of group 3 compared to group $1(P<.0004)$. On the contrary, the mean level of IgM in the sera of group 4 was $(1.72 \pm 0.185 \mathrm{mg} / \mathrm{mL})$ and there was no significant difference between group 4 and group $1(P<.6)$. In addition, the effect of BSA treatment on IgM levels in the sera of the control group (group 2) was previously investigated and it was concluded that the IgM level was within the normal level after treatment $(1.71 \pm 0.158 \mathrm{mg} / \mathrm{m} ; P<.16)$. However, nonsignificant differences were found (Table 1) in both IgA and IgG level 
TABLE 2. Effect of anti-BSA IgM antibodies on turbidimetric assay.

\begin{tabular}{|c|c|c|c|c|c|c|}
\hline \multirow{2}{*}{ Sample ID } & Group 1 & Group 2 & \multirow{2}{*}{$\begin{array}{l}\text { Decrease in IgM } \\
\text { concentration }(\%)\end{array}$} & Group 3 & Group 4 & \multirow{2}{*}{$\begin{array}{l}\text { Decrease in IgM } \\
\text { concentration }(\%)\end{array}$} \\
\hline & $\begin{array}{l}\text { Serum IgM level } \\
(\mathrm{mg} / \mathrm{mL})\end{array}$ & $\begin{array}{l}\text { Serum IgM level } \\
\quad(\mathrm{mg} / \mathrm{mL})\end{array}$ & & $\begin{array}{c}\text { Serum IgM level } \\
(\mathrm{mg} / \mathrm{mL})\end{array}$ & $\begin{array}{l}\text { Serum IgM level } \\
\quad(\mathrm{mg} / \mathrm{mL})\end{array}$ & \\
\hline 1 & 1.55 & 1.51 & 2.6 & 2.4 & 1.90 & 20.8 \\
\hline 2 & 1.62 & 1.6 & 1.2 & 2.3 & 1.4 & 39.1 \\
\hline 3 & 1.57 & 1.56 & 0.6 & 2.2 & 1.8 & 18.2 \\
\hline 4 & 1.89 & 1.88 & 0.5 & 2.23 & 1.5 & 32.7 \\
\hline 5 & 1.52 & 1.5 & 1.3 & 2.1 & 1.8 & 14.3 \\
\hline 6 & 1.88 & 1.88 & 0.0 & 1.98 & 1.83 & 7.6 \\
\hline 7 & 1.7 & 1.7 & 0.0 & 2.00 & 1.70 & 15 \\
\hline 8 & 1.8 & 1.78 & 1.1 & 2.4 & 1.51 & 37.1 \\
\hline 9 & 1.87 & 1.86 & 0.5 & 1.9 & 1.8 & 5.3 \\
\hline 10 & 1.89 & 1.86 & 1.6 & 2.2 & 1.93 & 12.3 \\
\hline $\begin{array}{l}\text { Mean } \\
\text { SD }\end{array}$ & $\begin{array}{l}1.73 \\
0.154\end{array}$ & $\begin{array}{l}1.71 \\
0.158\end{array}$ & - & $\begin{array}{l}2.17 \\
0.173\end{array}$ & $\begin{array}{l}1.72 \\
0.183\end{array}$ & - \\
\hline
\end{tabular}

of group 3 compared to normal individuals of group 1 $(P<.26$ and $P<.32)$.

These results were validated by measuring the concentration of serum IgM in 10 selected HEV infected sera using a turbidimetric assay (Table 2). The results from the turbidimetric assay demonstrated that the differences between normal and HEV-infected sera that were not pretreated with BSA (groups 1 and 3 ) were significant (1.73 \pm $0.154 \mathrm{mg} / \mathrm{mL}, 2.17 \pm 0.173 \mathrm{mg} / \mathrm{mL} ; P<.001)$. In addition, the levels of IgM detected with and without BSA pretreatment in unaffected groups (groups 1 and 2) were essentially identical $(1.73 \pm 0.154 \mathrm{mg} / \mathrm{mL}, 1.71 \pm 0.158 \mathrm{mg} / \mathrm{mL}$; $P<.88$ ), while in the affected groups (groups 3 and 4) they were significantly different $(2.17 \pm 0.173 \mathrm{mg} / \mathrm{mL}$, $1.72 \pm 0.183 \mathrm{mg} / \mathrm{mL} ; P<.001)$. However, after pretreatment with BSA, the means of groups 2 and 4 were essentially identical $(1.71 \pm 0.158 \mathrm{mg} / \mathrm{mL}, 1.72 \pm 0.183 \mathrm{mg} / \mathrm{mL}$; $P<$.96). Hence pretreatment of sera from normal or HEV-infected individuals with BSA leads to removal of the differences in IgM detected by ELISA or by turbidimetry.

\section{DISCUSSION}

We had access to serial serum specimens collected over 4 months from 40 hepatitis $\mathrm{E}$ patients. The demonstration of antibodies that interact with BSA in HEV-infected sera initiated a controversial debate on the utility of BSA antibodies as a disease marker and on the role of BSA in HEV. Our data suggest a high frequency of BSA/antibody crossreaction among HEV patients.

Previous studies demonstrated that IgM antibody levels were very high after illness onset, declined a little over several weeks, and then declined rapidly to low levels over the next 4 to 6 months. This is typical of IgM responses to other acute, self-limited, systemic viral infections $[23,24]$. The weeks-long duration of markedly elevated
IgM levels after disease onset means that diagnosis using even relatively insensitive IgM detection methods should be successful, even if patients come to medical attention late. Moreover, the months-long duration of IgM responses to HEV may be of benefit to hepatitis E outbreak investigations, since these typically commence months after the index case occurs. A sensitive IgM test should be able to identify most disease cases from late-convalescent phase serum specimens. Additionally, since many HEV infections are known to be subclinical [25], sensitive tests for IgM may enable identification of all infected persons rather than those with disease only. This problem has directed our research towards other possible immunological factors likely to be present in HEV patients, in the attempt to elucidate further the complex immuno-pathogenetic interactions of the disease: our finding of BSA-antibody interaction in HEV sera, leading to inaccuracies in IgM estimation by ELISA, represents a move in this direction.

In order to overcome this problem of antibody interaction with BSA, the sera were preincubated with BSA to eliminate this interaction. Interestingly, after removal of antibodies that interact with BSA, the IgM level appears to be similar between the affected and unaffected groups (Figure 2, Table 2) hence, after pretreatment with BSA, IgM levels alone do not appear to be a reliable measure of HEV infection.

The presence of antibodies that interact with BSA in HEV-infected patients may reflect the increased production of autoantibodies, and then lead to humoral immune abnormalities. This is best explained by suggesting that there is an interaction producing spurious immuno-precipitation as well as a circulating immunoglobulin which is capable of binding other autologous immunoglobulins which may well interact with other immune factors, thus participating in vivo in the complex immunopathological events which occur in HEV infected sera. 
In conclusion, this study indicates that the presence of antibodies reacting with BSA in sera from $\mathrm{HEV}$-infected patients may play a major pathogenetic role by the generation of autoantibodies. However, the time course for the development of antibodies before onset of clinical HEV is unknown, which might be most sensitive or specific for predicting future development of the disease activity. The high prevalence of elevated BSA/antibody interactions in HEV patients enhances the clinical utility of this immune marker due to polyclonal B cell activation or autoantibodies generation. Finally, the presence of HEV antibodies may help to explain the immunological abnormalities and extra-hepatic disorders, thereby providing an opportunity for early intervention that may be used for predicting disease in at-risk populations. The findings in this study can demonstrate the power of using BSA test towards the prediction and diagnosis of complex diseases such as HEV and may provide some new insights into antibody response to HEV.

\section{REFERENCES}

[1] Bradley D, Andjaparidze A, Cook EH Jr, et al. Aetiological agent of enterically transmitted non-A, nonB hepatitis. J Gen Virol. 1988;69(3):731-738.

[2] Kane MA, Bradley DW, Shrestha SM, et al. Epidemic non-A, non-B hepatitis in Nepal. Recovery of a possible etiologic agent and transmission studies in marmosets. JAMA. 1984;252(22):3140-3145.

[3] Bryan JP, Tsarev SA, Iqbal M, et al. Epidemic hepatitis $\mathrm{E}$ in Pakistan: patterns of serologic response and evidence that antibody to hepatitis E virus protects against disease. J Infect Dis. 1994;170(3):517521.

[4] Seriwatana J, Shrestha MP, Scott RM, et al. Clinical and epidemiological relevance of quantitating hepatitis E virus-specific immunoglobulin M. Clin Diagn Lab Immunol. 2002;9(5):1072-1078.

[5] Thomas DL, Yarbough PO, Vlahov D, et al. Seroreactivity to hepatitis $\mathrm{E}$ virus in areas where the disease is not endemic. J Clin Microbiol. 1997;35(5):12441247.

[6] Paul DA, Knigge MF, Ritter A, et al. Determination of hepatitis E virus seroprevalence by using recombinant fusion proteins and synthetic peptides. I Infect Dis. 1994;169(4):801-806.

[7] Mast EE, Alter MJ, Holland PV, Purcell RH. Evaluation of assays for antibody to hepatitis $\mathrm{E}$ virus by a serum panel. Hepatitis E virus antibody serum panel evaluation group. Hepatology. 1998;27(3):857861.

[8] Lin CC, Wu JC, Chang TT, et al. Diagnostic value of immunoglobulin G (IgG) and IgM anti-hepatitis E virus (HEV) tests based on HEV RNA in an area where hepatitis E is not endemic. J Clin Microbiol. 2000;38(11):3915-3918.
[9] Wang Y, Zhang H, Li Z, et al. Detection of sporadic cases of hepatitis E virus (HEV) infection in China using immunoassays based on recombinant open reading frame 2 and 3 polypeptides from HEV genotype 4. J Clin Microbiol. 2001;39(12):4370-4379.

[10] Li K, Zhuang H, Zhu W, et al. A preliminary study on hepatitis E virus antibody IgG and IgM for the diagnosis of acute hepatitis E. Zhonghua Nei Ke Za Zhi. 1999;38(11):733-736.

[11] Zhang JZ, Im SW, Lau SH, et al. Occurrence of hepatitis $\mathrm{E}$ virus IgM, low avidity IgG serum antibodies, and viremia in sporadic cases of non-A, -B, and -C acute hepatitis. J Med Virol. 2002;66(1):40-48.

[12] Yu C, Engle RE, Bryan JP, Emerson SU, Purcell RH. Detection of immunoglobulin $\mathrm{M}$ antibodies to hepatitis E virus by class capture enzyme immunoassay. Clin Diagn Lab Immunol. 2003;10(4):579-586.

[13] Takahashi M, Kusakai S, Mizuo H, et al. Simultaneous detection of immunoglobulin A (IgA) and IgM antibodies against hepatitis E virus (HEV) is highly specific for diagnosis of acute HEV infection. J Clin Microbiol. 2005;43(1):49-56.

[14] Beretta B, Conti A, Fiocchi A, et al. Antigenic determinants of bovine serum albumin. Int Arch Allergy Immunol. 2001;126(3):188-195.

[15] Hilger C, Grigioni F, De Beaufort C, Michel G, Freilinger J, Hentges F. Differential binding of IgG and IgA antibodies to antigenic determinants of bovine serum albumin. Clin Exp Immunol. 2001;123(3):387-394.

[16] Laemmli UK. Cleavage of structural proteins during the assembly of the head of bacteriophage T4. $\mathrm{Na}$ ture. 1970;227(5259):680-685.

[17] Fairbanks G, Steck TL, Wallach DFH. Electrophoretic analysis of the major polypeptides of the human erythrocyte membrane. Biochemistry. 1971; 10(13):2606-2617.

[18] Engvall E, Perlman P. Enzyme-linked immunosorbent assay (ELISA): quantitative assay of immunoglobulin G. Immunochemistry. 1971;8(9):871874.

[19] Engvall E. Quantitative enzyme immunoassay (ELISA) in microbiology. Med Biol. 1977;55(4):193200.

[20] Malkus H, Buschbaum P, Castro A. An automated turbidimetric rate method for immunoglobulin assays. Clin Chim Acta. 1978;88(3):523-530.

[21] Haroun M. Effect of anti-immunoglobulin antibodies on serum IgA in type 1 diabetes mellitus. Bull Alex Fac Med. 2002;38:169-174.

[22] Haroun M. Avoiding antibodies interferences on serum IgA detection in rheumatoid arthritis. $\mathrm{J} \mathrm{Med}$ Sciences. 2004;4:294-299.

[23] Decker RH, Kosakowski SM, Vanderbilt AS, Ling CM, Chairez R, Overby LR. Diagnosis of acute hepatitis A by HAVAB-M, a direct radioimmunoassay for IgM anti-HAV. Am J Clin Pathol. 1981;76(2): $140-147$. 
[24] Goldsmith R, Yarbough PO, Reyes GR, et al. Enzyme-linked immunosorbent assay for diagnosis of acute sporadic hepatitis E in Egyptian children. Lancet. 1992;339(8789):328-331.

[25] Clayson ET, Vaughn DW, Innis BL, Shrestha MP, Pandey R, Malla DB. Association of hepatitis E virus with an outbreak of hepatitis at a military training camp in Nepal. J Med Virol. 1998;54(3):178-182. 


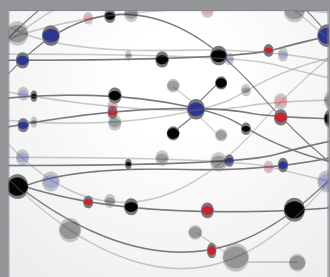

The Scientific World Journal
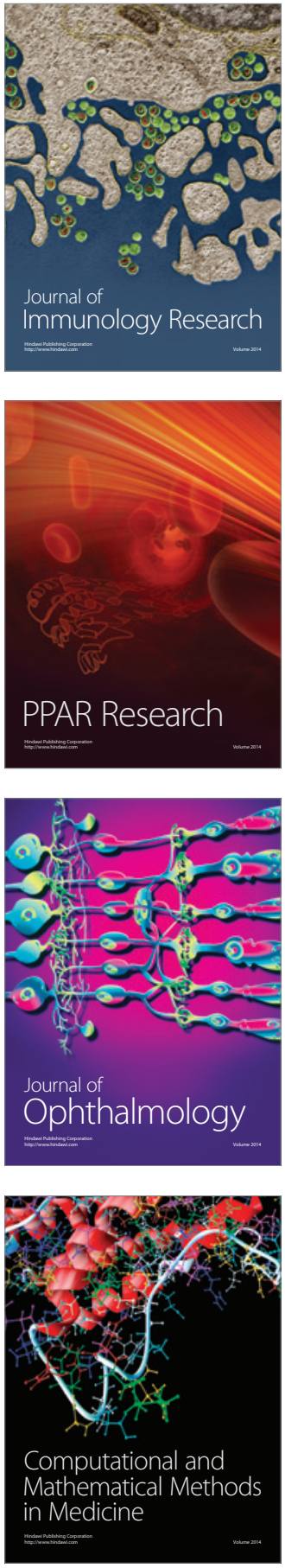

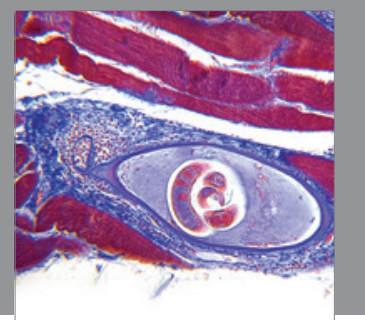

Gastroenterology

Research and Practice
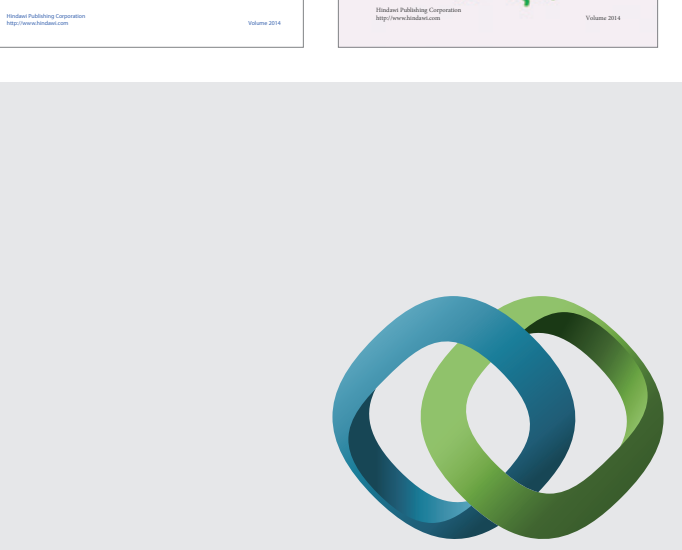

\section{Hindawi}

Submit your manuscripts at

http://www.hindawi.com
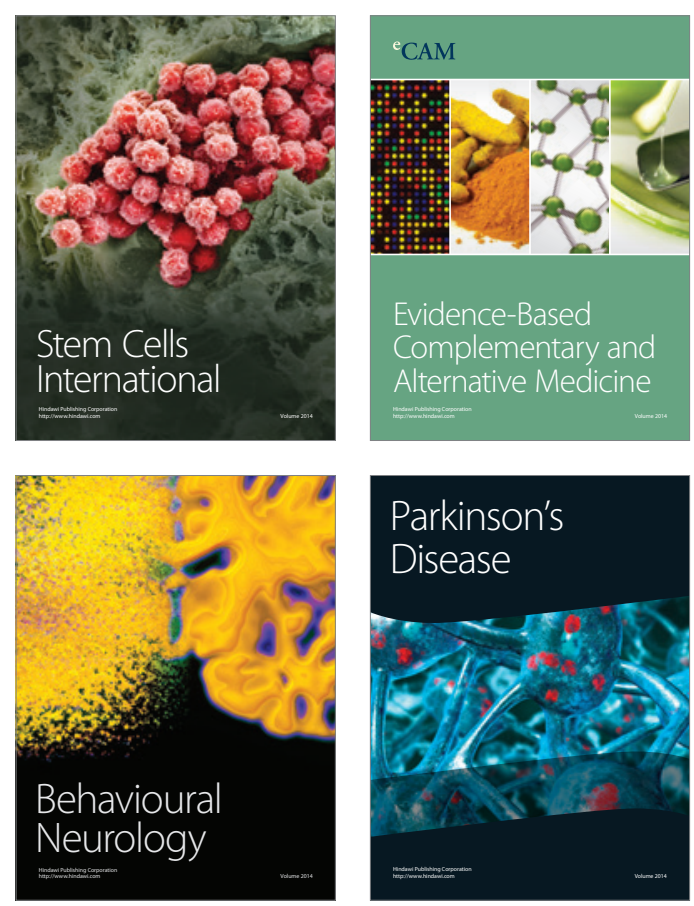

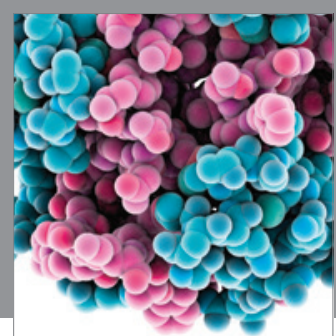

Journal of
Diabetes Research

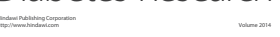

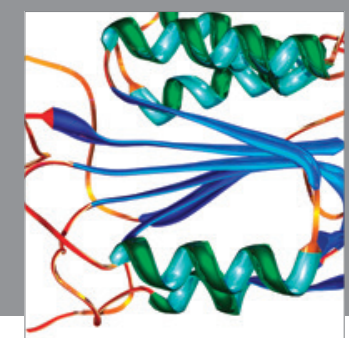

Disease Markers
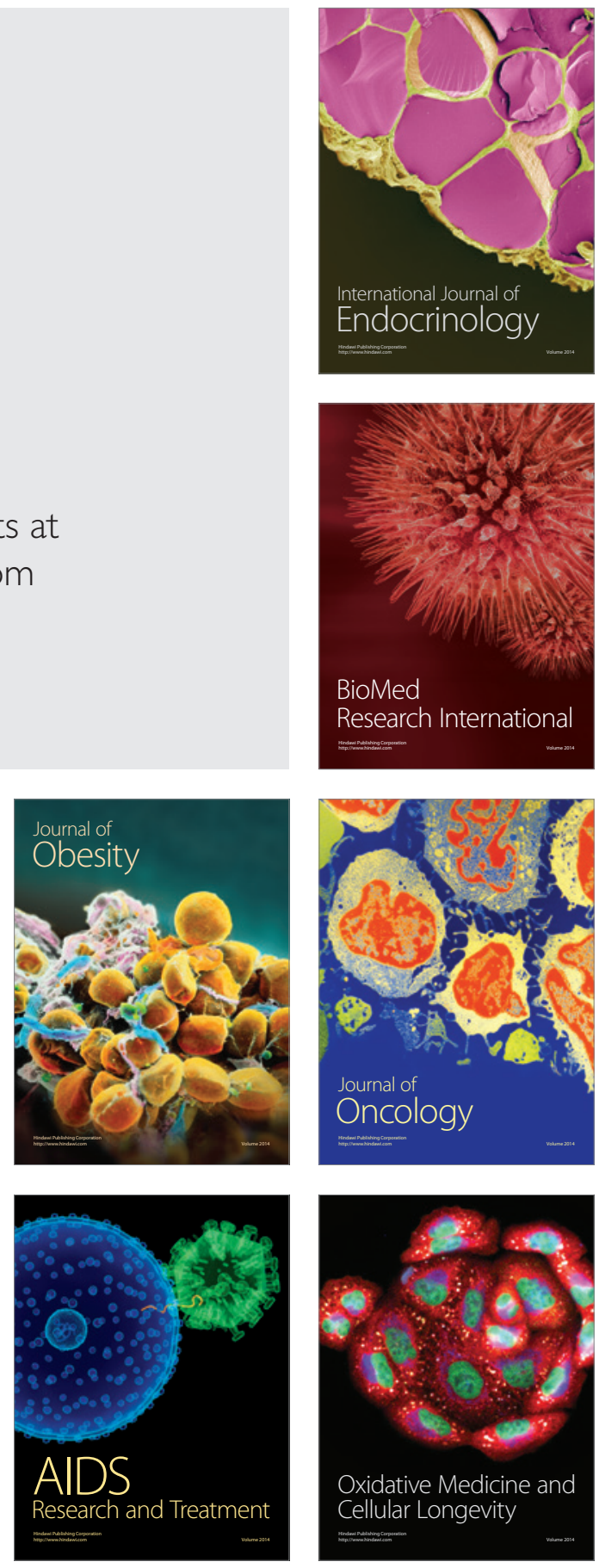